\section{Circular Rainbow}

IN the notice given in NATURE (Sept. I I, p. 465) of the beautiful circular rainbow that is seen in the spray of the Montmorenci Falls near Quebec, the expression in the heading, "seen from a hill-top" will convey an erroneous idea without some explanation. The complete circle is only seen by getting down in the spray to the edge of the low rocks, within a few inches of the level of the water, and the circular bow then passes down to the feet on each side; it is indeed most perfectly seen by turning round and stooping down to look back between the legs, when the complete circle is seen without interruption from the feet. The bow is small in diameter, and is a narrow band, appearing nearer to the eye than an ordinary spray rainbow. I had the pleasure of seeing it on August 25, on the occasion of the British Association Canadian visit.

15. Augustus Road, Birmingham, October 13

\section{To Find the Cube of any Number by Construction}

Prof. Karl Pearson has kindly referred me for a simple graphical construction for any positive or negative power of any rational quantity whatever to Egger's "Grundziige einer graphischen Arithmetik." This method, he informs me, is reproduced in Cremona's "Il calcolo graphico." I was of course aware that there were several simple constructions. I was induced to write upon the subject owing to the unexpected discovery that there was a line in the geometry of the triangle which enabled one to obtain the cube of a number.

October 14

R. TUCKER

\section{EXPLORATIONS IN ICELAND ${ }^{1}$}

\section{THE LAVA DESERT OF ÓdÁðAHRAUN}

$\mathrm{O}^{\mathrm{N}}$ July 25 we set out for the southern Dyngjufjöll, in order to examine Askja. All previous explorers of that volcanic locality have taken the northern route from Svartárkot, but no one has hitherto approached it from the east, from Herdubreio, any advance from that side having been deemed impracticable. This I wanted to test for myself, and shaped my course from the tent (pitched, as before said, to the south of Herrubreið) in a direct line on the wide gap that opens in Askja to the east. The whole intervening country was one continuous succession of lavas, so effectively covered with pumice and scoria from the great explosion of 1875 , fortunately for us, that the whole was really one scoriac plain, the pumice boulders measuring generally one to two cubic feet, some more, some less. If it had not been for this scoriaceous cover, these lavas would have proved pretty certainly utterly impassable for horses. We took good care to keep to the crests of the thickest pumice-drifts, and though such travelling is rough enough for horses, yet they sustain no great harm, because the pumice is so light and brittle. Under the south-eastern spurs of Dyngjufjoll we came upon a lake, shallow, but of considerable magnitude, of the existence of which there was no previous knowledge. About midway between Herðubreit and Dyngjufjöll the country begins to rise up towards the aforementioned gap in Askja. Askja is a cauldron-shaped valley in the centre of Dyngjufjöll, which is an enormous complex of mountains 4500 feet high. This valley contains innumerable craters which have erupted at various periods; the sides of this valley rise to between 700 and 800 feet, but out of the aforementioned gap lavas have flowed over the lower country outside all the way down to Ódáðahraun, forming an enormous oval of an average incline of $4^{\circ} 33^{\prime}$. When we came close up to the gap, the scoriæ ceased, and at once the lava became exceedingly difficult to pass. But by aid of frozen snowdrifts filling dips and dints in the slopes, we managed to thread our way along, and thus actually to get into the valley; only one single tongue of lava we had to cross without the aid of snowdrifts-one which, though very narrow, we had the greatest difficulty in getting our ponies over. Having at last succeeded in this, we rode along frozen snowdrifts under the southern slopes of the Askja valley, and thus reached actually on horseback the craters which exploded here in 1875 . Previous visitors to Askja have entered the valley through a pass in the mountains inclosing the valley from the north, outside which pass they have had to abandon their horses and to reach the craters on foot over an almost impassable lava-stretch in the bottom of the valley, taking four to five hours in passing the distance from the pass to the craters. From our tent by Lindaá it took us nine hours to reach the craters, but the return route we accomplished in seven. We now left our ponies provided with their fodder beside the large eruptor of 1875 , and set off on foot to examine the locality in every direction, spending for that purpose the whole of the bright night and a portion of the next day. So over-covered was Askja with snow that journeying along here was like journeying in the heart of winter. The whole mass of Dyngjufjöll is made up of palagonite breccia interspersed with layers of basalt. Into this mass Askja sinks in the shape of a shallow basin, and may derive its present form partly from certain stretches of it having sunk down in consequence of eruptions, partly from that natural dint or basin-formation of valleys which is so strikingly common to tufa mountains in Iceland. But the supposition that the whole of this valley, about sixteen square miles English, is one crater, the result of one great volcanic explosion, is unwarranted. In the great eruption of 1875 a very considerable extent of ground "fell in" in the south-eastern corner of the Askja valley round the craters, and the vertical precipice of the fractured crust of the earth on the side of the Askja valley measures, according to Prof. Johnstrup's survey, 740 Danish feet; that at the opposite side in the mountains is at least double in thickness. The vertical walls of the precipices exhibit in a clear manner the successive layers of lava which fill the bottom of the Askja valley. In the earth-slip thus created there was, in 1876 , a small lake of dull-green colour, circular, and measuring about 4000 feet in diameter. This lake now fills the whole bottom of the slip and measures 10,000 feet in length. In 1876 the temperature of the water was $22^{\circ}$ Celsius $\left(71^{\circ} .6 \mathrm{~F}\right.$.), but has now fallen to $14^{\circ} \mathrm{C}$. $\left(57^{\circ} \cdot 2 \mathrm{~F}\right.$.). The crater, which by its explosion covered the east country with pumice and scoriz in 1875 , is situated in the north-eastern brim of the fissure, and is 300 feet in diameter and 150 feet deep; its outer circumference flat, and built up of scoriac ashes, its inside cylindric and perpendicular. In 1876 this crater only emitted steam, now it has turned into a boiling cauldron of clay, the clay mud at the bottom being gray with an admixture of bluish green tint, boiling and wallopping incessantly; through the southeastern part of its bottom there issues by a subterranean vent a thick column of steam with loud roars and reports, and all around this column smaller fissures issue thinner jets of steam and fumes. Interspersed with the scoriæ in Askja and on the eastern side of the surrounding mountains are found small glazed grayish-blue pieces of trachyte thus formed by the last eruption: among these there are some found of which one-half, or a portion, is reduced to pumice, while the remainder retains its trachytic constituency. In the south-eastern corner of the dip right up from the water are also found a number of craters from which radiate rents and gulfs honeycombed with innumerable fumaroles and crater-tubes from which clouds of steam roll up high above the crests of the mountains, the roar and boom from which are heard to a great distance, resembling the rumbling sound of steam let off from many boilers at once. Deposits of sulphur are already visible round a number of the fumaroles, and yellow-green patches of sulphur show all about the precipices, where every chink and rupture lets off sulphurous fumes. In the eastern part of the slip the scoriaceous layers 
have recently been rent asunder by a rift 150 to 200 feet deep, reaching from the summit of the mountain all the way down to the water. Across this rift there is no way of passing, and, in order to reach the south-eastern corner of the slip, it is necessary to scramble up to the top of the mountain, so as to get round the crevasse. It is difficult to form any adequate conception of the titanic grandeur of Nature at this spot. He who has once had the opportunity of viewing it from the precipice of the earth-slip will never forget the impression. Having finished my survey here, we returned to our tent the same way we had come, glad of rest, exhausted with fatigue and want of sleep as we were, after thirty-six hours' continuous travel.

On July 28 I set out on my return journey to Mývatn, taking a direct course across the northern part of Odátahraun to the farmstead of Granavatn, on the southern side of the lake (Mývatn). This I did with a view to rediscovering the whole of the old highway, the eastern end of which I had already traced. First we shaped our course directly for the northern end of Herðubreiðarfjöll, guided by the beacons to which I have alluded already. We crossed a pass, dividing the easternmost neck of the mountains from the main range, in the eastern approach to which an excessively rough lava, split by innumerable rifts, had to be traversed, in which we succeeded by the mode of scrambling. On the verge of one of the rifts in this lava we came upon a dilapidated beacon, and again upon another on the western defile from the pass, from where we threaded our way along the skirts of a recent and very rough lava, directing our course for the central neck of Herðubreiðarfjöll. Here we were intercepted by two enormous rifts, Ioo to I 50 feet deep, divided by an earth-slip one mile broad, and twenty miles long. With the exception of Almannagjá and Hrafnagjá, near Thingvellir, these are the largest rifts in Iceland. Having succeeded in bringing our caravan over the eastern brim down alongside the spurs of an isolated "fell," we charged the western brim in vain for a long time until we came upon a sort of steep pass, up through which we brought our ponies, and found upon the verge three dilapidated beacons, which showed that we were still on the traces of the old highway. From this spot beacons may be still traced in a straight direction for Fremri Námur, but recent rifts and lavas have destroyed the road, which, though I now knew its direction, I could pursue no farther. Here, namely, we thought we had overcome all difficulties, but found soon to our cost that we were mistaken. Some distance to the east of Fremri Námur there is a quite recent-looking lava, very long, but narrow, which evidently has welled out of a lava fissure here in 1875, when, besides Askja, Mývatnsöræfi also were in a state of volcanic activity. This lava is not connected with the well-known more northerly lavas of 1875 , wherefore its existence has been overlooked hitherto; and when Johnstrup constructed his map of the lava of Mývatnsöræfi, he was not aware of the fact that the same rift which gave birth to the northern lavas of 1875 had, further to the south, given existence to this, which measures fully one-half of the others. To the east of this lava the earth is all cut up by bottomless cracks, over which it was truly a breakneck business to pass. Across some we had to urge our ponies to jump, others we passed by means of natural bridges of loose boulders, which frequently gave way. This was travelling with one's life in one's hand, and to me it is the greatest wonder that no harm resulted to man or beast. To attempt crossing this new lava was entirely out of the question, so we had to bend our way southward along its eastern skirts until we might get round its southern spur. At this end of the lava I observed a peculiar rift not more than thirty to forty feet long and three to four inches broad, on which twelve craters were situated, in every way formed and shaped as large craters are generally, but of such miniature dimensions, that they looked as if they had been intended for toys for children; the aperture of most of them was only four to five inches in diameter, that of the largest two feet. These had, however, squirted forth dashes of lava to the distance of sixty feet. When at last we had reached the southern end of the lava, a new trouble intervened in the shape of what appeared to be an endless rift, and utterly impassable. We had therefore to make up our minds to spending the night, or whatever time might be required, in finding a passage across this barrier; and after five hours' weary struggle we at last managed to scramble across where the main crack split up into smaller ones. This was hard work for our ponies, languishing with thirst and with hardly anything to eat; and perhaps only a degree less arduous for us, who in the matter of food and drink were no better off. Having crossed this serious barrier, we came upon a much more even tract of lava, and presently, to our intense relief, struck a pool of water under a snowdrift in a dent in the lava, where, having watered our horses, we treated them to the last scanty remainder of their fodder, and then went on our way. In the early morning we reached the valley called Heilagsdair in Bláfjöll, where we were obliged to pitch our tent in order to give the exhausted animals the benefit of the scanty pasture which a few plots of grass offered. After a few hours' welcome sleep we broke up hastily, a gale of wind with rain and sand-drift having burst upon us in the meanwhile. Our course now lay across the spurs radiating to the eastward from Blafjöll, but such was the violence of the hurricane that it was well nigh impossible to sit on horseback without being blown away, and equally difficult to guard against the despairing animals being blown out of our hands into the howling wilderness. After some really considerable trouble and hardship, we managed to scramble down a precipitous gorge into the upland plateau on which the Lake of Mývatn has found its bed. After having more than once lost our bearings on these lower lava*wilds, we succeeded at last in striking the homestead of Grænavatn, exhausted with our exertions, and were glad of a grateful rest in good beds, after having spent a fortnight in a tent, with our saddles for pillows.

Reykjahlíx, near Mývatn, August 4

TH. THORODDSEN

\section{STORAGE BATTERIES}

THE importance and desirability of an efficient and economical storage battery have been very widely recognised, but it is at the present time pretty generally felt that no existing form of storage battery is perfect, and that they are on the whole extravagant and wasteful to an extent sufficient to more than compensate for their undeniable convenience. It is perfectly certain that their employment has not become at all general, and that they have failed to realise the somewhat sanguine hopes of their early promoters.

It seems worth while to examine into the causes of this partial failure, and to inquire how far the evil opinion held by many practical men concerning our present method of storing electrical energy is justifiable.

One of the main objections is that storage involves a loss of some 50 per cent. of the whole. Now all methods of storing and transmitting energy involve some loss. To say that any particular method involves a loss of 50 or even 90 per cent. is not to condemn it utterly. There are many cases when the convenience of storage outweighs the evil of waste altogether ; three principal ones may be specified.

(I) When the power of the source would be otherwise so completely wasted ihat every fraction of it stored is clear gain. This is the case of much terrestrial water power. The energy of the tides or of Niagara is enormous, and wholly wasted so far as human activity is con- 